\title{
EMBEDDING OF RURAL BUSINESSES IN THE SOUTH MORAVIAN REGION
}

\author{
Milada Št’astná, Tereza Kniezková, Miloslava Náplavová ${ }^{1}$
}

Received 14 June 2011; Accepted 23 September 2011

\begin{abstract}
The aim of the paper is to present original findings obtained from the analysis of the SMEs (Small and Medium-Sized Enterprises) embedded in the South Moravia Region (Czech Republic). Data collected from the survey during 2010 was analyzed in the context of the DERREG project and the results were set with respect to globalization tendencies. The first part of the Business network questionnaire for the Czech case study took place during the spring. Forty three Small and MediumSized firms out of 550 approached replied to the email questionnaire. The responses provided us with a valuable insight in to how SMEs located in various territorial settings are able to develop and maintain a certain structure to their business network. In the second stage of activities, structured interviews were conducted during the summer of 2010 with follow-up questions from the questionnaire as well as the completion of an "Actor map". The analysis allowed the interviewee to classify the firms according to the dominant function of their networks. Results found that the majority of companies were not affected significantly by the economic crisis. The worst years for them were 2008 and 2009 where profits decreased in all areas of activity. Small businesses agreed that in a time of crisis it is much harder to succeed in the market against supermarkets and wholesalers, who can afford to lower the prices. A positive side of the crisis can be the fact that much more companies try to break into foreign markets where they get offered better prices for some commodities. The majority of respondents agreed that the economic crisis is retreating and they look optimistically into the future.
\end{abstract}

Keywords: rural businesses, South Moravia, survey, trade, global economic crisis

Souhrn: Cílem příspěvku je představit původní výsledky autorů zjištěné analýzou MSP (malých a středních podniků) Jihomoravského kraje (ČR). Data získaná průzkumem v roce 2010 byla analyzována $v$ kontextu projektu DERREG a výsledky byly vztaženy k problematice globalizace. První část dotazníkového šetření obchodní sítě $v$ české případové studii probíhala na jaře. Čtyřicet tři malých a středních podniků z 550 oslovených odpovědělo na dotazník zaslaný e-mailem. I přes takto nízkou návratnost nám odpovědi poskytly cenné informace o tom, jak jsou malé a střední podniky nacházející se $v$ tomto regionu schopny rozvoje a udržení struktury své obchodní sítě. Druhá fáze šetření se zabývala strukturovanými rozhovory, které

\footnotetext{
1 Doc.Ing. Milada Št’astná, PhD., Ing. Tereza Kniezková, Ing. Miloslava Náplavová, Department of Applied and Landscape Ecology, Faculty of Agronomy, Mendel University in Brno, Zemědělská 1, 61300 Brno, Czech Republic, *email: stastna@mendelu.cz; tereza.kniezkova@mendelu.cz; miloslava.naplavova@mendelu.cz
} 
následovaly $v$ letním období a podrobněji rozebíraly otázky $v$ dotazníku. $V$ průběhu rozhovorů byl hlavní důraz kladen především na vyplňování tabulky tvořící základ hlavního výstupu této fáze, tzv. "Mapu hlavních aktérư". Díky této analýze bylo možno zařadit firmy podle dominantní funkce jejich sítí. Většina firem nebyla krizí významně ovlivněna. Nejhoršími lety pro ně byly 2008 a 2009, kdy se snížil zisk ve všech oblastech jejich činností. Malé podniky se shodly na tom, že $v$ době krize je mnohem těžší uspět na trhu $v$ porovnání se supermarkety a velkoobchody, které si mohou dovolit nižší ceny. Pozitivní stránkou krize může být skutečnost, že se mnohem více firem snaží proniknout na zahraniční trhy, kde jsou nabízeny lepší ceny některých komodit. $V$ pohledu do budoucna byla většina respondentů optimisty a shodla se na tom, že krize je na ústupu.

Klíčová slova: zemědělské podniky, Jižní Morava, dotazníkové šetření, obchod, globální ekonomická krize.

\section{Introduction}

Economic, environmental, and political changes are re-shaping many rural areas and their communities across Europe, within the broader context of globalization. Woods (2007) provides the following definition of globalization "a dynamic and multifaceted process of integration and interaction that enrolls localities into networks of interconnectivity organized at the global scale and facilitating the global circulation of people, commodities, ideas and representations". He examines the reconstitution of rural places under globalization, highlighting the interaction of local and global actors, and of human and non-human ones, to produce new hybrid forms and relations. Contemporary globalization has triggered a necessary change of attitude also from small rural businesses regarding internationalization and cooperation (Dubois and Hedström 2011). As part of this, networking between firms is important for establishing and maintaining business relations, nationally and internationally. Accordingly, Dubois and Hedström (2011) have proposed that rural development initiatives should pay attention to 'network brokering', that is facilitating the development of business relations and partnerships between firms within a network, and helping small firms to find reliable business partners in other parts of the region, Europe or even worldwide. The objective of this paper is to introduce and primarily analyze rural businesses in the South Moravia region and position them with respect to the above mentioned globalization tendencies.

\section{State of the Art}

\section{Rural Europe and businesses}

During the past two decades specifically, three strong tendencies have led us to re-assess the relative importance of resources to local rural economies. Firstly, the mechanization and concentration of exploitation have resulted in a general decrease in importance of the primary sector within rural communities, with their socio-professional structure increasingly resembling that of more urban environments. Secondly, and by consequence, the accelerating demise of traditional rural life has distanced individuals from farm work and, by the same token, substantially modified the foundations of contemporary rural landscape appreciation. Finally, the last few decades were also marked by an increase in the mobility of individuals. The importance of these three phenomena is such that they are actually re-drawing the social and economic configuration of rural areas (Domon 2011).

Building on debates around exogenous and endogenous development, networks have particular utility in helping to understanding diverse forms of rural development. There are two main "bundles" of networks: "vertical" networks - that is, networks that link rural spaces into longer commodity chains, especially in the agro-food sector - and "horizontal" networks - that is, distributed network forms that link more general economic non-agricultural activities and processes within and beyond rural spaces. It has been argued that rural development strategies must take heed of network forms in both domains and that rural policy should be recast in network terms (Mudroch 2000). 
More recently changes in information technology, logistics, and working patterns (such as increases in home working), and the increasing dominance of the service sector, have allowed businesses, especially SMEs, to take advantage of quality of life assets, particularly freedom from congestion (Copus et al. 2006). Some rural areas are considered to have advantages in terms of the configuration of their business networks, or clusters, which may be a seedbed for entrepreneurial activity, or may constitute a local/regional innovation system. Local "embeddedness" and links between economic activity and social capital may account in part for their success (Granovetter 1985, Stathopoulou et al. 2004).

Addressing firms through the view of globalization and regional development, as in the DERREG project on which this paper is based, necessitates a multiscalar approach to networks. Indeed, globalization as an economic process not only leads to the development of business operations outside their domestic market, but also influences their capacity to be more competitive in their own domestic market, in the light of stronger external competition. Consequently, it is likely that globalization processes will have an impact on the configuration of a firm's territory of operations. This engages the firm into a multiscalar process of networking from the local scale to the global. In the same manner, addressing the concerns on contemporary regional development (sharpening the regions' comparative advantage, making the region more attractive, or overcoming the territorial constraints) leads the regional and local authorities and agencies to initiating strategic alliances and rapprochement on multiple scales in order to position their region in multiple webs of governance (Woods 2007). Consequently, the necessary integration of globalization and regional development concerns bring into light the necessity to put the firms in their social space and in the scheme of power/policy relational context.

The Czech Republic has had many years of consistent government support aimed at the stabilisation of rural areas. Programmes focused on the socio-economic stabilisation of rural areas have been funded from both national and European Community sources, and aid granted in the framework of other thematically focused operational programmes directed to rural areas ${ }^{2}$. Several studies have been completed in the Czech Republic regarding rural development, including for example, research on rural tourism, on understanding the attitudes of entrepreneurs and of the rural population towards entrepreneurship, and on the determination of limiting factors in development. These studies have shown that insufficient awareness of available support as well as its inaccessibility for small business present difficulties.. Other obstacles, we can mention, include the current legislation system, bureaucracy, the state of communication and tourist infrastructure, fears of neighbors' intolerance and losing privacy and also unfamiliarity and limited experience (Rýglová 2007).

There remain significant regional variations in the composition of rural economies as mentioned for example by Sedlacek et al., (2009) for Germany or McDonagh et al., (2010) for Ireland. When observing the development potential of Czech rural areas, we must take into account different possibilities and prerequisites of development of rural municipalities. It is therefore necessary to precisely diversify individual types of support for Czech rural areas, so that the offered support can be effectively used to ensure necessary investments and activities in rural municipalities (Perlín 2010).

\section{Description of the region}

The South Moravian Region (Jihomoravský kraj) occupies the south-eastern part of Moravia. With an area of $7196 \mathrm{~km}^{2}$, the South Moravian Region is the fourth largest in the Czech Republic, and includes the districts of Blansko, Brno-city, Brno-countryside, Břeclav, Hodonín, Vyškov and Znojmo (Figure 1). The southern borders with Austria and Slovakia are partly formed by Morava and Dyje rivers, and the region also shares short strips of the border with the South Bohemian Region to the west, with Vysočina Region to the north-west, Pardubice Region to the north, Olomouc Region to the north-east and Zlín Region to the east. The population of the region in 2008 was 1,147,000 inhabitants (1,155,338 in March 2011).

\footnotetext{
${ }^{2}$ http://www.un.org
} 

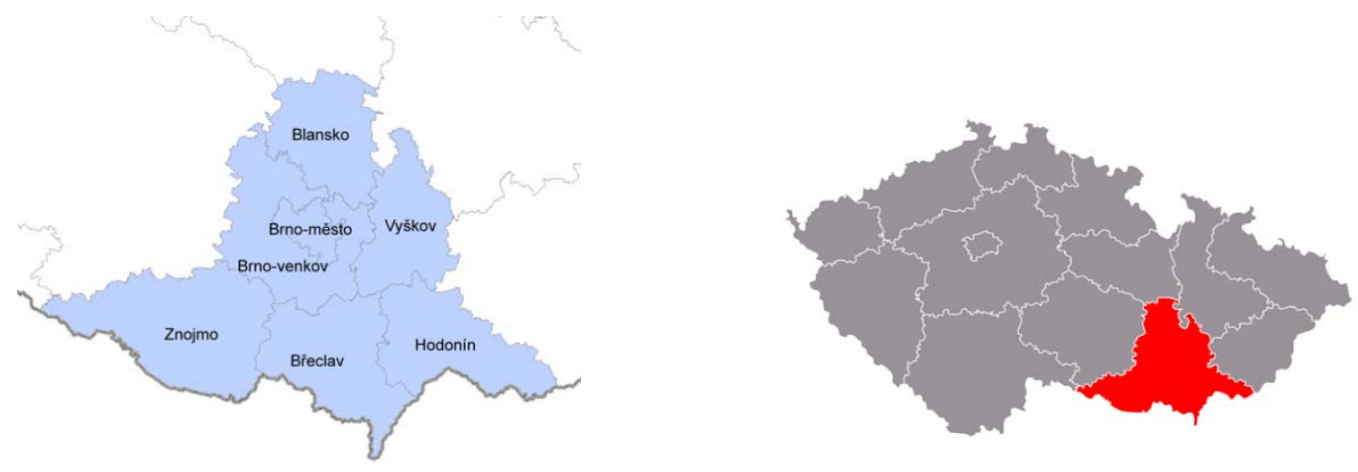

Fig 1. Districts in the South Moravian Region. (Source: Portal of Regional information services.)

\subsection{Economic situation}

The South Moravian regional economy, historically dominated by industry, has significant agriculture, reflecting natural conditions (greengrocery, wine growing) and related foodstuff industry. The regional economy was strongly affected by social and economic transformation since the end of the socialist period. In particular, industry went through significant changes to the range and structure of the employed labor force. Traditional large enterprises have closed, and most of the labor force has shifted to the tertiary sector.

The biggest employers in the private sector of the region are still large firms located in Brno district and industrial zones, with small and medium sized enterprises largely associated with agriculture. Nonetheless, the presence of small and middle firms in the region is advantageous as they are strongly embedded in the region, whereas larger companies are more footloose and prone to relocate for economic benefit. Larger companies have also been harder hit by economic transformations, with many closing, such that most of the workforce is now employed by smaller firms. Larger companies additionally tend to be concentrated in the Brno, Brnocountryside and Blansko districts, and are largely absent from the southern part of the region where unemployment is highest.

Entrepreneurial activity increases along with population growth, and is generally higher in cities where there are higher concentrations of inhabitants and more services needed (180 enterprisers / 1,000 inhabitants in 2001) than in rural communes (143 enterprisers). However, there also exist municipalities with outstanding entrepreneurial activity in rural areas. Their business activity depends on the location: it is higher in municipalities with a good location near big cities where people can benefit from entrepreneurial opportunities in these cities. At the same time there is higher entrepreneurial activity in larger municipalities with peripheral positions, where competition between services is lower due to remoteness.

The South Moravian region has a significant position in agricultural production in the Czech Republic, specializing in fruit growing and viticulture. Almost $90 \%$ of vineyards in the Czech Republic are located in the region, especially in Břeclav, Hodonín and Znojmo districts (almost $48 \%$ growth within Břeclav district). More than one fifth of Czech orchards can also be found in the region. Indeed agriculture has faced dramatic changes resulting from the transition from socialism to the free market economy after 1989 with further changes occurring in 2004 when the Czech Republic joined the European Union and its Common Agricultural Policy.

\section{Methods}

During February and March 2010, a database of the companies in the South Moravian countryside was created from the Administrative Business Register of the Czech Republic ${ }^{3}$, which is an information system allowing searches of businesses registered in the country. The register mediates visualization of data held in various registers of the state administration where such data is located (so called source registers). Communities in South Moravia were

\footnotetext{
${ }^{3}$ available at http://wwwinfo.mfcr.cz/ares/ares.html.cz
} 
searched on the Cities Online portal ${ }^{4}$ that offers municipalities free publication of mandatory information under the Act No. 106/2000 Coll. For each village, active firms were searched. For some villages it was necessary to search for companies by the Classification of economic activities (CZ-NACE). Recorded information for some companies did not include the number of employees or areas of activity and therefore these companies could not be included in our compiled database. The database includes firms according to set parameters (micro 9 or less employees; small enterprises 10-49 employees and medium enterprises 50-249 employees in rural areas). The completed database for the South Moravia region comprises a total of 555 firms from six rural districts (Blansko, Břeclav, Brno-County, Hodonín, Vyškov, Znojmo).

In the first phase of the research, micro and small businesses were contacted by telephone and asked whether they wished to receive our electronic questionnaire in pdf or doc format (8 pages in Czech language). All sectors of activities, except pure agriculture, were considered in the survey. In the questionnaire, the respondent had to assess their degree of interaction with a set of actors divided into 4 territorial scales: regional, national, European and the rest of the world. The topics were: clients and suppliers; collaboration with other companies; support from institutional actors; sources of financing; membership in formalized networks and associations. For each topic, the respondent had to score their level of interaction with those actors from 0 (no interaction) to 4 (strong interaction). In the question relating to clients and suppliers, the respondent had to provide estimated proportion of sales and purchases occurring at the 4 different territorial levels. Finally, the respondent had to assess the impact of the recent global financial crisis on their relationship with the previous actors-by-scale.

Received questionnaires went through explorative analysis and then were converted into XML format and analysed by MS Excel. Afterwards, obtained tables and graphs went through a further evaluation. Questions were evaluated quantitatively as responses had the four-point scale according to their importance for the firm (1 to 4) from moderate to strong involvement. The questionnaire evaluation focused (except for general company information) particularly on findings of their relationships to suppliers and customers as well as their sales and purchases. Finally a typology of firms according to the degree of internationalization of corporate transactional spaces was created, combining the results of responses regarding the company activities.

\section{Results}

The total number of contactedcompanies was 550. In detail: 62 questionnaires were sent to the districts of Blansko, Brno-county and Vyškov-county with 11 returned. The total number of questionnaires sent to districts of Břeclav, Hodonín and Znojmo was 186, of which 23 were returned (see Figure 2). Due to the low response rate follow-up contact with selected companies was also made. However, our strategy had only a small effect in the districts of Blansko, Vyškov and Brno-countryside, but a higher return was noticed after repeated telephone contact in Břeclav, Hodonín and Znojmo districts. Medium-sized businesses in the region were also contacted as a part of the strategy due to the insufficient number of small companies replying. Only 98 medium-sized companies were found and contacted (36 in the districts of Blansko, Vyškov and Brno - countryside, 62 companies in the districts of Břeclav, Hodonín and Znojmo), and we obtained eleven completed questionnaires. Overall, 45 replies were received in total, with 43 good enough to be used for the subsequent analysis and our exploration of positioning of SMEs in the region.

\footnotetext{
${ }^{4}$ available at www.mesta.obce.cz
} 


\section{Legend:}



010000 Crop and livestock production, hunting and related activities

220000 Manufacture of rubber and plastic products

310000 Manufacture of furniture

250000 Manufacture of fabricated metal products, except machinery and equipment

100000 Manufacture of food products

110000 Beverages

160000 Wood, wood, cork, straw and plaiting materials, except furniture

280000 Manufacture of machinery and equipment J. N.

130000 Textiles

200000 Manufacture of chemicals and chemical products

210000 Manufacture of basic pharmaceutical products and pharmaceutical preparations

680000 Real estate

260000 Manufacture of computer, electronic and optical equipment

Fig 2. Geographical location of responding firms. (Source: authors.)

\section{S A L E S}

\begin{tabular}{|c|c|c|c|c|c|c|c|}
\hline \multirow[b]{2}{*}{$\infty$} & \multirow[b]{2}{*}{ Local } & Local & \multicolumn{2}{|c|}{ Domestic National } & \multicolumn{3}{|c|}{ InternationalizedGlobalized Total } \\
\hline & & 9 & 2 & & 1 & 1 & 13 \\
\hline [1工 & Domestic & 1 & 4 & & 2 & 2 & 10 \\
\hline$\varangle$ & National & 1 & 0 & & 0 & 1 & 2 \\
\hline 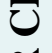 & Internationalized & 0 & 2 & & 2 & 2 & 6 \\
\hline b & Global & 2 & 0 & & 1 & 6 & 12 \\
\hline A & Total & 13 & 8 & & 6 & 12 & 43 \\
\hline
\end{tabular}

Tab 1. Typology of firms according to their transactional space. (Source: authors.)

Regarding the typology of firms, the results did not show a strong limitation to the regional level. From the 43 valid responses, only 16 firms fall into the category "local" (sales and purchases within the region - blue colour in the table), 14 companies belong to the category "internationalized interfaces", and 11 to the category of "globalized" firms. Only 2 firms can be seen as strictly national. 


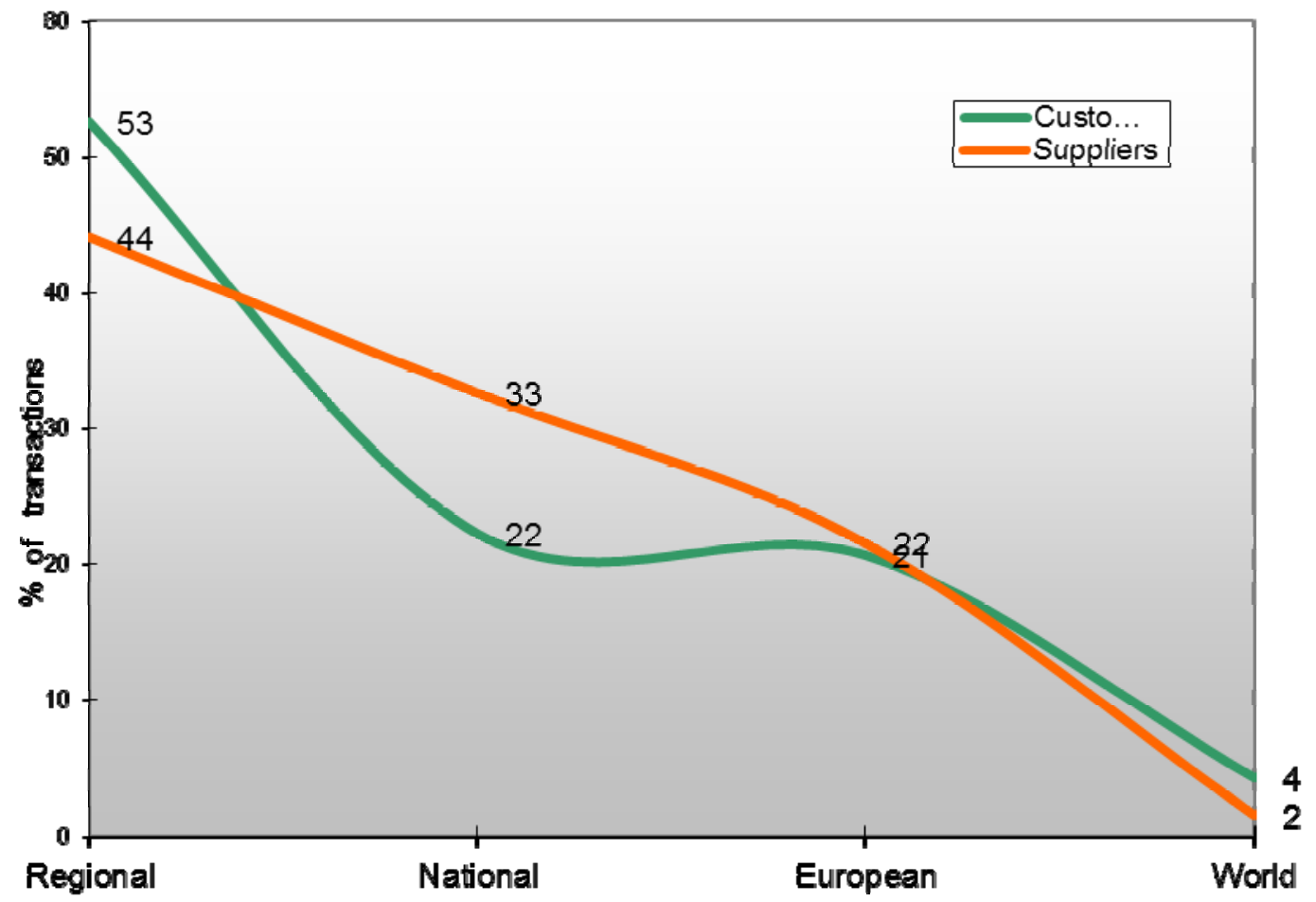

Fig 3. Average proportion of transactions taking place at different level for all valid responses (43). (Source: authors.)

Figure 3 describes the average volume of transactions at different scales, showing that suppliers located in the region correspond to $44 \%$ of total purchases and regional customers to $53 \%$ of the total purchases. This underlines the fact that the majority of firms' activities are operating inside the region. The results displayed in figure 4 show that even for firms that have an international profile, only a minority of the total transactions are taking place at world level. For Globalized firms, about $65 \%$ of the clients and $57,5 \%$ of the suppliers are located in Europe, and less than $3 \%$ of them outside Europe.

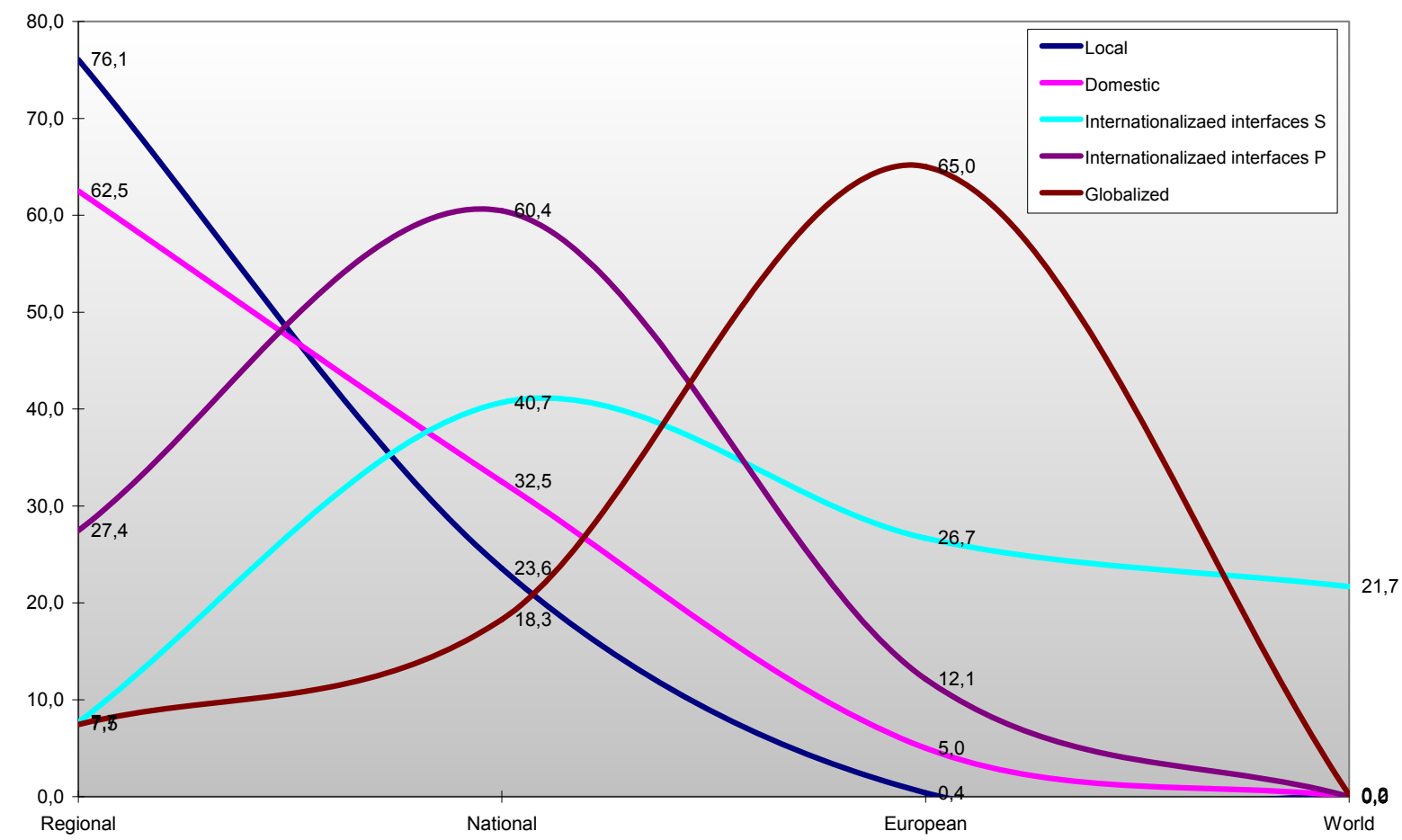

Fig 4. Average proportion of sales taking place at different levels by type of firms, according to the Index of Globalization (OECD 1997; Herdzina et al., 2004). 
The results displayed in figure 4 show that even for firms that have an international profile, only a minimum of the total transactions are taking place at world level. For Globalized firms, about $65 \%$ of the clients and $57,5 \%$ of the suppliers are located in Europe, and less than $3 \%$ of them outside Europe. National powerhouse's category even disappeared as there is no crystallized transition activity at this level.

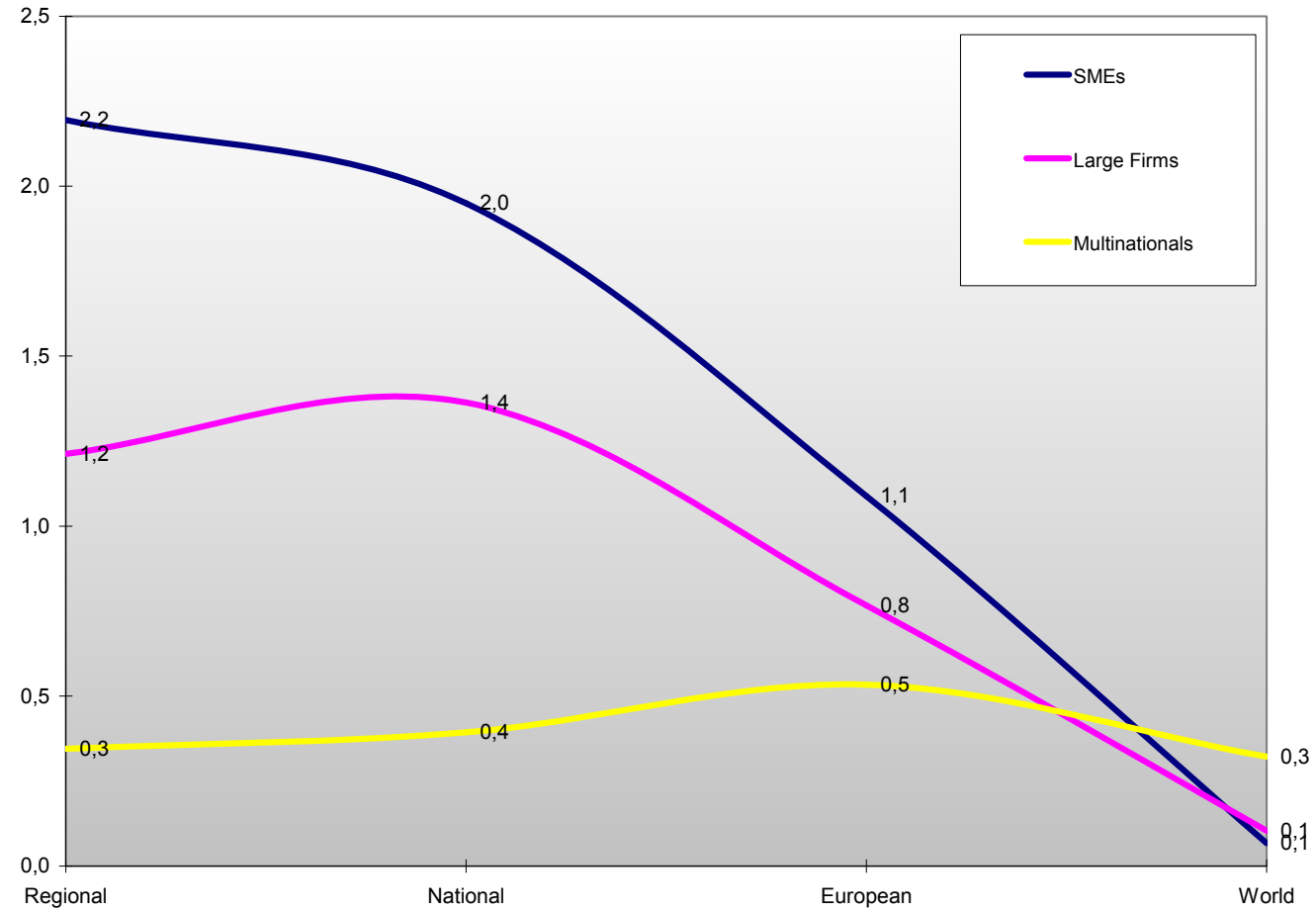

Fig 5. Importance (average proportion) of "collaboration with other firms" at four different levels. (Source: authors.)

Concerning the hypothesis that firms will establish strong relationship with firms in closer territorial scales (Dubois, 2010), it is possible to say that the hypothesis was confirmed for firms between European and World levels, especially for firms with multinational relationships, whose most important collaborations are at the European scale. For large firms, the most important collaborations were at the national scale, whereas for SMEs, collaborations within the region were most important (Figure 5).

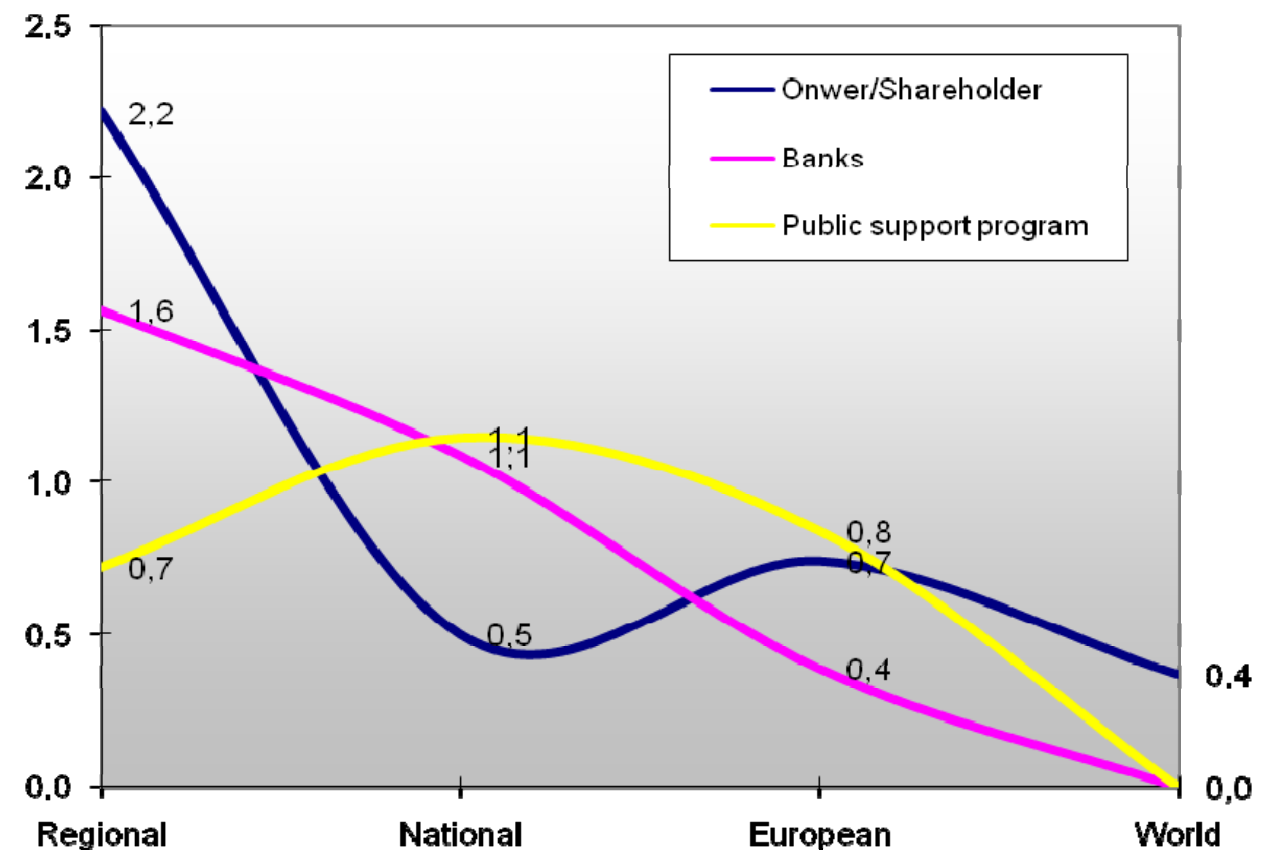

Fig 6. Financial space. Percentage of finances flowing from different sources into the firms. (Source: authors.) 
The most important sources of finance are "owners" and shareholders in the region, and regional banks. (Fig. 6). Generaly it is possible to say, that firms draw most of their financial capital from regional and national sources, and very comes from the world level. However, the European scale is of growing importance as a source of finance within all categories.

The Results regarding the global economic crisis can be seen as surprising. The highest impact was noticed at the regional level, especially with respect to "Clients" and "Cooperations". However, this is due to the fact that most of the transactions of SMEs are still on the regional level within the South Moravian region. The "Clients" category showed the highest impact of the crisis, which was relatively clear since higher prices of products limited buyers' purchasing power, so they have turned to cheaper suppliers. This has had a knock-on effect, and cases of dismissed workers and the closure of some businesses was also registered, as well as impacts on collaboration and cooperation. Relations with banks and with research institutions and public institutions do not appear to have been as dramatically affected, and impacts on relations with national and international partners were less affected than those with regional clients and partners.

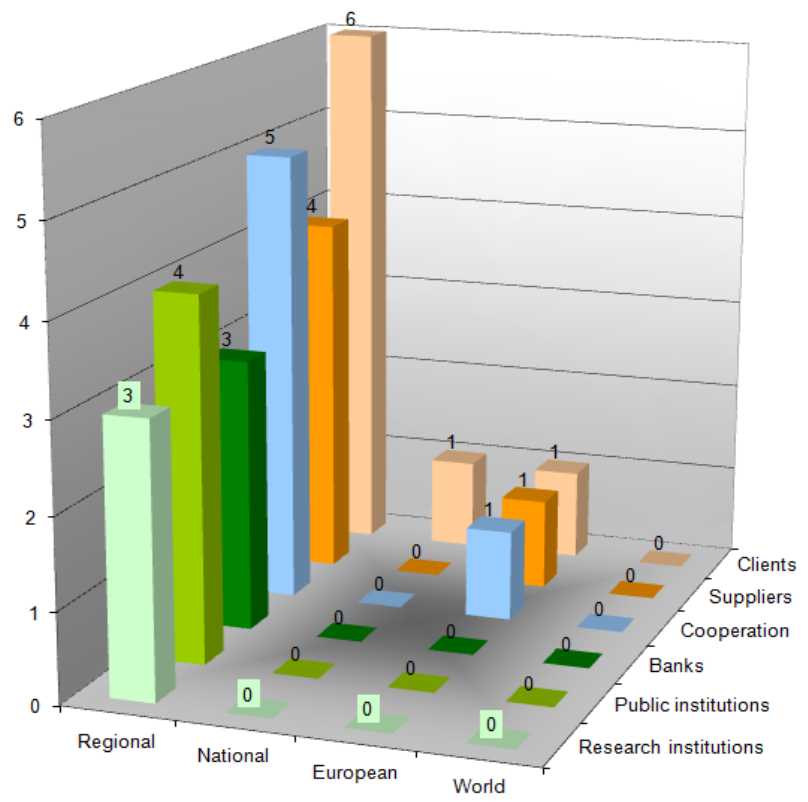

Fig 7. Impact of Global Economic Crisis into the particular category at four different levels. (Source: authors.)

\section{Conclusion}

The survey of small and medium enterprises in the South Moravian region was realized during February and March 2010. A database of South-Moravian rural businesses was created, and a combination of phone and electronic contacts was used to approach the companies. Despite the high number of companies approached, the amount of returned questionaries was low, but nevertheless the results give us an insight into the transactional spaces of SMEs in the South Moravian region. The analysis classified firms according to the dominant pattern of their business relationships, and whilst revealing the presence of some SMEs in South Moravia with international transactions, it primarily showed that the majority of SMEs in South Moravia operate largely within the region in terms of sales, purchases, access to finance capital, and collaborations.

The research also examined the impact of the global economic crisis since 2008, and found that the majority of companies were not affected significantly by the crisis. The worst years for SMEs were 2008 and 2009, as profits decreased in all areas of their activities, but the majority of respondents agreed that the crisis is retreating and they looked optimistically to the future. Small businesses agreed that in a time of crisis it is much harder to succeed in the market against supermarkets and wholesalers, who can afford to lower their prices. As such, some have attempted to diversify their markets, and one positive aspect of the crisis has been that more companies have tried to break into foreign markets where they get offered better prices for their commodities. 


\section{Acknowledgement}

The study was part of DERREG project funded by the European Union Seventh Framework Programme (FP7) Socio-Economic Sciences and Humanities (SSH-CT-2008-225204).

References

1. Copus, A., Hall, C., Barnes, A., Dalton, G., Cook, P., Weingarten, P, Baum, S., Stange, H., Lindner, C., Hill, A., Eiden, G., McQaid, R., Grieg, M. \& Johansson, M. (2006). Study on Employment in Rural areas, Final Deliverable, commissioned by DG Agriculture, SAC Aberdeen. http://researchrepository.napier.ac.uk/id/eprint/2865 (June 2011).

2. Domon, G. (2011). Landscape as resource: Consequences, challenges and opportunities for rural development. Landscape and Urban Planning, 100(4), 338-340. Doi: 10.1016/j.landurbplan.2011.02.014.

3. Dubois, A. (2010). Firms in network - The case of SMEs in peripheral, sparsely populated regions of Sweden. The 2010 Conference of the Regional Studies, Pécs. CD ROM

4. Dubois, A. \& Hedström, M. (2011). Striving for Local Development - Brokering firm networks in the North of Europe. Regional Studies Association Annual International Conference. April 2011. 1-20. Newcastle upon Tyne, UK

5. Granovetter, M. (1985). Economic Action and Social Structure: The Problem of Embeddedness. The American Journal of Sociology, 91(3), 481-510.

6. Herdzina, K., Findeis, A., Fleischmann, S., Wander, C., Piasecki, B. \& Rogut, A. (2004). European rural SMEs in the context of Globalization and Enlargement, in Labrianidis, L. (Ed.), The future of Europe's rural peripheries, Aldershot: Ashgate.

7. McDonagh, J., Farrell, M., Mahon, M. \& Ryan, M. (2010). New opportunities and cautionary steps? Farmers, forestry and rural development in Ireland. European Countryside, 2(4), 236-251. DOI: 10.2478/v10091-010-0016-2.

8. Murdoch, J. (2000). Networks - a new paradigm of rural development? Journal of Rural Studies, 16(4), 407-419. Doi: 10.1016/S0743-0167(00)00022-X.

9. OECD 1997. Globalisation and small and medium enterprises (SMEs). Paris: OECD.

10. Perlín, R. (2010). Theoretical approaches of methods to delimitate rural and urban areas. European Countryside. 2(4), 182 - 200. DOI: 10.2478/v10091-010-0013-5.

11. Rural Development Programme (RDP) of the Czech Republic. European Network for Rural Development, 4/2010.

12. Rýglová, K. (2007). Limiting factors in the field of business activities in rural tourism. Agricultural Economics - Czech, 53,(9), 421-431.

13. Sedlacek, S., Kurka, B. \& Maier, G. (2009). Regional identity: a key to overcome structural weaknesses in peripheral rural regions? European Countryside, 1(4), 180- 201. DOI: 10.2478/v10091-009-0015-3.

14. Stathopoulou, S., Psaltopoulos, D. \& Skuras, D. (2004). Rural entrepreneurship in Europe: A research framework and agenda. International Journal of Entrepreneurial Behaviour \& Research, 10 (6), 404-425. Doi: 10.1108/13552550410564725.

15. Steger, M. (2003). Globalization: a very short introduction. Oxford: Oxford University Press.

16. Woods, M. (2007). Engaging the global countryside: globalization, hybridity and the reconstitution of rural place. Progress in Human Geography, 31(4), 485-507. Doi: $10.1177 / 0309132507079503$. 